\title{
Analytical Estimation of the Residual Drift of Reinforced Concrete Columns under the Ultimate Displacement Capacity
}

\author{
Sinan Cansız ${ }^{1 *}$ \\ ${ }^{1}$ Construction Technology, Vocational High School, Istanbul Aydin University, 34295 Istanbul, Turkey \\ *Corresponding author, e-mail: sinancansiz@aydin.edu.tr
}

Received: 05 May 2020, Accepted: 09 December 2020, Published online: 18 December 2020

\begin{abstract}
Reinforced concrete columns are the most important structural elements that determine the ductility of the structures. The main parameters affecting the behavior of reinforced concrete columns are axial load level, shear span, percent of longitudinal reinforcement and percent of transverse reinforcement. The aim of this study is to examine residual damage behavior of RC columns under cyclic loading similar to the earthquake loads combined depend on variable axial load level, spanning to depth ratio, longitudinal reinforcement ratio and transverse reinforcement ratio. When the results of experiments are examined, it can be seen that the residual drift ratio of reinforced concrete columns can be used to characterize the damage occurred in the structure after earthquake or loading. In addition, the performance level of the reinforced concrete columns according to the residual drift ratio is defined in FEMA356. As a result of this study, the analytical equation that calculates the residual drift ratio of the reinforced concrete columns at the ultimate displacement limit is proposed.
\end{abstract}

Keywords

RC column, residual drift ratio, damage, seismic analysis

\section{Introduction}

In recent years, the design of reinforced concrete structural systems has been made on the basis of force or displacement-based approaches. Reinforced concrete elements are designed to be stronger than earthquake loads in forcebased approaches. Irreparable damages were occurred in the buildings exposed to the earthquake after the earthquakes in the 1990s (e.g.: Kobe 1995, Northridge 1995, Loma Prieta 1989). As a result, the performance-based design principle has been started to be used in seismic codes due to the economic losses. Performance-based design is the approach in which the target damage expected to occur after the earthquake is defined. The use of performance-based design to reach post-earthquakes functionality of critical structures is most commonly thought of as applied to structures (e.g.: hospitals, fire stations).

Residual damages occur depending on the magnitude of the earthquake in reinforced concrete structures exposed to earthquake loads. Experimental and analytical studies have been carried out by many researchers to identify these damages [1-3]. Lehmann et al. [4] suggest that key damage states of residual cracking, cover spalling, and core crushing can best be related to engineering parameters, such as longitudinal reinforcement tensile strain and concrete compressive strain, using cumulative probability curves. Erduran and Yakut [5] determined the damage functions of reinforced concrete columns depend on drift. According to Priestley and Kowalsky [6], it is shown that current code-based design approaches, which imply a constant ductility factor, will generally result in damage levels that are highly variable. Goodnight et al. [7] the importance of displacement history and its effects on performance limit states, the relationship between strain and displacement, and the spread of plasticity in RC structures are investigated. Cheng et al. [8] have researched on the influencing factors for residual displacements of RC bridge columns subjected to earthquake loading. In addition, the residual drift ratio becomes larger due to the increase of the maximum lateral drift ratio, the displacement ductility factor, and the aspect ratio. Then, a larger longitudinal reinforcement ratio can induce a larger residual drift ratio due to the contribution of the bar pulling out deformation. A new post-earthquake seismic performance evaluation method 
for structures which takes into account residual deformation is suggested by Yazgan and Dazio [9]. The post-earthquake residual deformations and the traceable damage to the structure are considered to obtain developed predicts of the maximum deformations that took place during the earthquake. A new plastic hinge model was proposed in the study by Bae and Bayrak [10]. The proposed plastic hinge model has been compared with existing models, taking into account the effect of the axial load.

In the study conducted by Vui et al. [11], the damage indices commonly used were investigated and a new damage model was proposed According to this model, residual displacement is considered as the most important parameter of the damage and the energy-related correlation is suggested. It has been stated that the results are usable by comparing the results obtained with the other damage models.

Residual drift can be shown as the most important indicator left by seismic loads on structures. Many seismic codes in the world use different methods in the performance of reinforced concrete structures. In these seismic codes, it is necessary to know the loading history in order to determine the performance of the building. It is difficult to determine the current performance in columns with limited knowledge. Within the scope of this study, the prediction of damage due to the residual drift ratio of reinforced concrete columns was investigated. According to this method, the performance level of the columns with limited knowledge can be found. The main words in the title start with capital letter, articles, and conjunctions with lowercase letters.

\section{Material and method}

The performance level of reinforced concrete columns is calculated by different methods in many seismic codes. The performance of reinforced concrete elements using the material strain values in Turkey earthquake building code are determined [12]. Panagiotakos and Fardis [13] provided formulations for chord rotation capacity at yielding and "ultimate" (at $20 \%$ strength drop), the latter through an empirical and a semi-empirical (i.e., based on the plastic hinge length) approach based on a large database of flexure-controlled experimental tests for RC elements. According to researchers, loading profile is needed to determine the current performance of the reinforced concrete column. However, in practice, the most important parameter that can be determined in existing building inspections for performance determination of buildings is the residual drift ratio. Therefore, defining the damage in terms of residual drift ratio could guide engineers during the implementation phase.

\subsection{Properties of the columns}

Within this study, columns investigated in previous experimental studies were used [14]. The properties of the columns examined in this paper are presented in Table 1.

Table 1 Properties of the columns

\begin{tabular}{|c|c|c|c|c|c|}
\hline Specimen Name & $L / h$ & $N / A_{c} f_{c}$ & $\rho_{t}$ & $\rho_{s h}$ & $f_{c}$ \\
\hline Ang No. 3 [15] & 4.00 & 0.38 & 0.015 & 0.006 & 23.6 \\
\hline Ang No. $4[15]$ & 4.00 & 0.21 & 0.015 & 0.004 & 25.0 \\
\hline Azizinamini et al. NC-2 [16] & 3.00 & 0.21 & 0.019 & 0.005 & 39.3 \\
\hline Azizinamini et al. NC-4 [16] & 3.00 & 0.31 & 0.019 & 0.003 & 39.8 \\
\hline Mo and Wang C1-1 [17] & 3.50 & 0.11 & 0.021 & 0.003 & 24.9 \\
\hline Mo and Wang C1-2 [17] & 3.50 & 0.16 & 0.021 & 0.003 & 26.7 \\
\hline Mo and Wang C1-3 [17] & 3.50 & 0.22 & 0.021 & 0.003 & 26.1 \\
\hline Nosho et al. No. 1 [18] & 7.64 & 0.34 & 0.010 & 0.001 & 40.6 \\
\hline Saatcioglu and Grira BG-1 [19] & 4.70 & 0.43 & 0.020 & 0.003 & 34.0 \\
\hline Saatcioglu and Grira BG-2 [19] & 4.70 & 0.43 & 0.020 & 0.005 & 34.0 \\
\hline Saatcioglu and Grira BG-3 [19] & 4.70 & 0.20 & 0.020 & 0.005 & 34.0 \\
\hline Saatcioglu and Grira BG-4 [19] & 4.70 & 0.46 & 0.029 & 0.003 & 34.0 \\
\hline Saatcioglu and Ozcebe U3 [20] & 2.86 & 0.14 & 0.032 & 0.006 & 34.8 \\
\hline Saatcioglu and Ozcebe U4 [20] & 2.86 & 0.15 & 0.032 & 0.009 & 32.0 \\
\hline Soesianawati No. 1 [21] & 4.00 & 0.10 & 0.015 & 0.002 & 46.5 \\
\hline Soesianawati No. 2 [21] & 4.00 & 0.30 & 0.015 & 0.003 & 44.0 \\
\hline Soesianawati No. 3 [21] & 4.00 & 0.30 & 0.015 & 0.002 & 44.0 \\
\hline Soesianawati No. 4 [21] & 4.00 & 0.30 & 0.015 & 0.002 & 40.0 \\
\hline Tanaka No. 2 [22] & 4.00 & 0.20 & 0.016 & 0.007 & 25.6 \\
\hline Watson No. 5 [23] & 4.00 & 0.50 & 0.015 & 0.003 & 41.0 \\
\hline Watson No. 6 [23] & 4.00 & 0.50 & 0.015 & 0.001 & 40.0 \\
\hline Zahn No. 7 [24] & 4.00 & 0.22 & 0.015 & 0.003 & 28.3 \\
\hline Kanda et al. 85STC-1 [25] & 3.00 & 0.11 & 0.016 & 0.004 & 27.9 \\
\hline Galeota et al. CB3 [26] & 4.56 & 0.30 & 0.060 & 0.008 & 80.0 \\
\hline Galeota et al. CB2 [26] & 4.56 & 0.20 & 0.060 & 0.008 & 80.0 \\
\hline Wehbe et al. A1 [27] & 3.83 & 0.10 & 0.022 & 0.001 & 27.2 \\
\hline $\begin{array}{l}\text { Xiao and Martirossyan, 8L19- } \\
\text { T10-0.1P [28] }\end{array}$ & 2.00 & 0.10 & 0.035 & 0.010 & 76.0 \\
\hline $\begin{array}{l}\text { Xiao and Martirossyan, 8L19- } \\
\text { T10-0.2P [28] }\end{array}$ & 2.00 & 0.20 & 0.035 & 0.010 & 76.0 \\
\hline $\begin{array}{l}\text { Xiao and Martirossyan, 8L16- } \\
\text { T10-0.1P [28] }\end{array}$ & 2.00 & 0.10 & 0.025 & 0.010 & 76.0 \\
\hline Sugano UC15L [29] & 2.00 & 0.36 & 0.019 & 0.006 & 118.0 \\
\hline Sugano UC15H [29] & 2.00 & 0.60 & 0.019 & 0.006 & 118.0 \\
\hline $\begin{array}{l}\text { Bayrak and Sheikh } \\
\text { AS-2HT [30] }\end{array}$ & 6.04 & 0.36 & 0.026 & 0.007 & 71.7 \\
\hline $\begin{array}{l}\text { Bayrak and Sheikh } \\
\text { AS-4HT [30] }\end{array}$ & 6.04 & 0.50 & 0.026 & 0.014 & 71.9 \\
\hline $\begin{array}{l}\text { Legeron and Paultre, } \\
\text { No. } 1006015 \text { [31] }\end{array}$ & 6.56 & 0.14 & 0.022 & 0.011 & 92.4 \\
\hline $\begin{array}{l}\text { Legeron and Paultre, } \\
\text { No. } 1006025[31]\end{array}$ & 6.56 & 0.28 & 0.022 & 0.011 & 93.3 \\
\hline $\begin{array}{l}\text { Legeron and Paultre, } \\
\text { No. } 1006040[31]\end{array}$ & 6.56 & 0.40 & 0.022 & 0.011 & 98.2 \\
\hline
\end{tabular}


Where $L / h$ is the shear span to depth ratio, $N / A f_{c}$ is axial load ratio, $\rho_{t}$ is longitudinal reinforcement ratio, $\rho_{s h}$ is transverse reinforcement volumetric ratio (TBEC-2018), $N$ is axial load, Ac is gross area and $f_{c}$ is concrete strength. Calculation of reinforcement ratios is shown in the Eqs. (1)-(2).

$\rho_{t}=\frac{A_{s}}{b d}$

$\rho_{s h}=\frac{A_{s h}}{b_{k} s}$

Where $A_{s}$ is longitudinal reinforcement total area, $b$ is column width, $d$ is effective depth, $A_{s h}$ is transverse reinforcement area, $b_{k}$ is core concrete width and $s$ is hoop spacing. The parameters taken into consideration in the selection of column properties are shear span to depth ratio, axial load ratio, longitudinal reinforcement ratio and transverse reinforcement ratio, respectively. In the columns selected within the scope of the study, these properties are determined in the value range allowed in the seismic codes. In addition, columns with high concrete strength are not included in the study. In order to ensure that the study is independent of the effect of concrete compressive strength, columns with frequently used concrete strength have been selected. In this context, the ranges of the columns properties value used in the study are shown in Table 2.

\subsection{Seismic analysis results of the columns}

The displacement capacity of RC elements has been investigated by many researchers in recent years. Some of the studies in this area are considered as limit values in the codes. In the nonlinear static procedure of TBEC-2018, in order to predict the performance level, the strain limits of concrete and reinforcement are used as the main parameters. EUROCODE-8 includes a part for the assessment of $\mathrm{RC}$ columns that proposes the calculation of chord rotations with the given equations in the code [32]. These equations are functions of many variables such as axial load ratio, longitudinal reinforcement ratio, transverse reinforcement ratio and yield strength of the transverse reinforcement.

Table 2 Ranges of the columns properties value

\begin{tabular}{lcc}
\hline \multirow{2}{*}{ Parameter } & \multicolumn{2}{c}{ Range of value } \\
& Minimum & Maximum \\
\hline Span to depth ratio $(L / h)$ & 2.86 & 7.64 \\
Axial load ratio $\left(N / A_{\partial} f_{c}\right)$ & 0.10 & 0.60 \\
Longitudinal reinforcement ratio $\left(\rho_{t}\right)$ & 0.010 & 0.060 \\
Transverse reinforcement ratio $\left(\rho_{s h}\right)$ & 0.001 & 0.009 \\
Concrete strength $\left(f_{c}\right)$ & 23.6 & 118.0 \\
\hline
\end{tabular}

FEMA 356 is the American pre-standard and commentary for the seismic rehabilitation of buildings [33]. The document expresses deformation limits, which are in the form of plastic rotations. In FEMA 356, deformation limits are specified in terms of plastic rotation for RC columns. Some seismic codes define the displacement capacity for reinforced concrete columns as an approximately $20 \%$ decrease in lateral load bearing capacity. Figs. 1-36 illustrate load-displacement curves with ultimate displacement capacity and residual displacement.

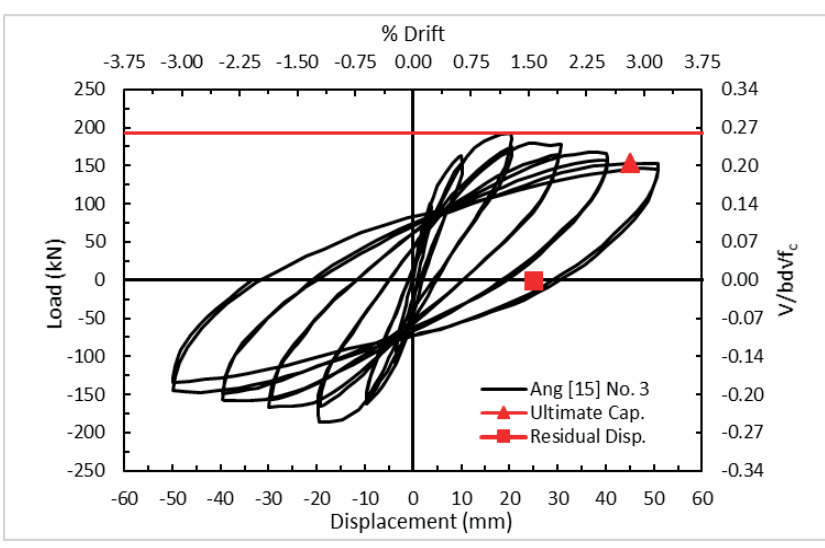

Fig. 1 Load-displacement curve of the Ang [15] No.3



Fig. 2 Load-displacement curve of the Ang [15] No.4

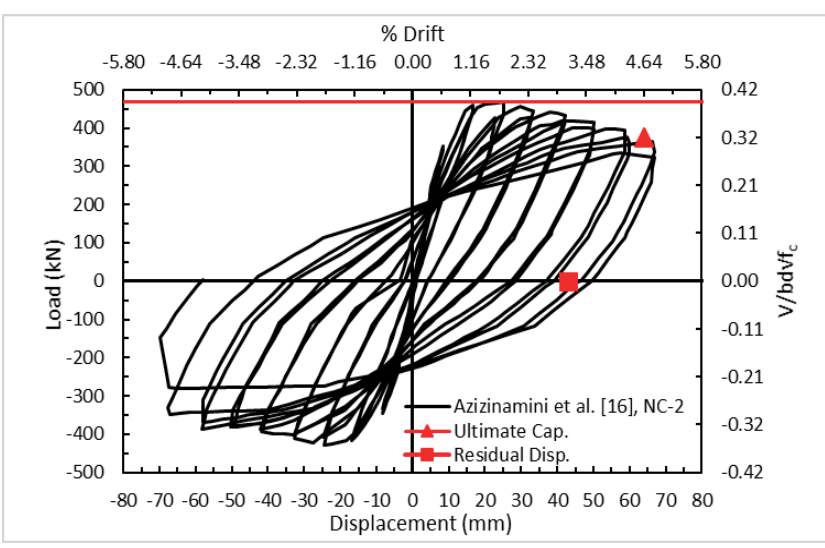

Fig. 3 Load-displacement curve of the Azizinamini et al. [16], NC-2 


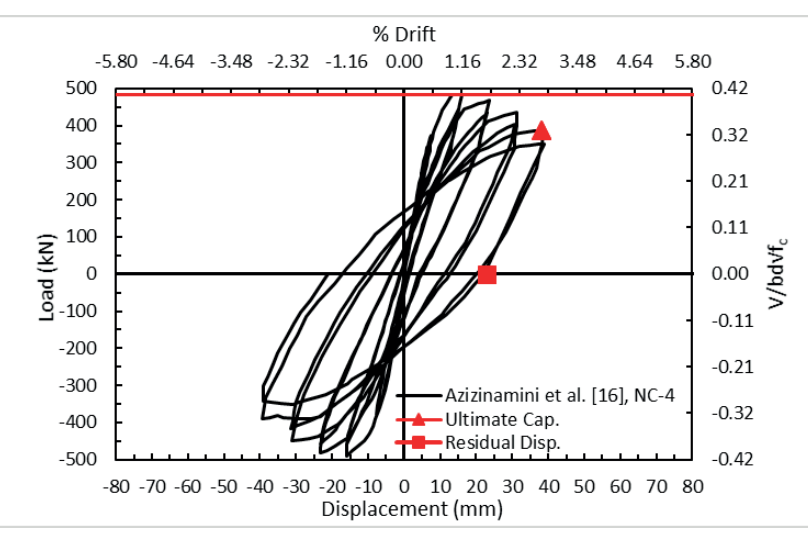

Fig. 4 Load-displacement curve of the Azizinamini et al. [16], NC-4

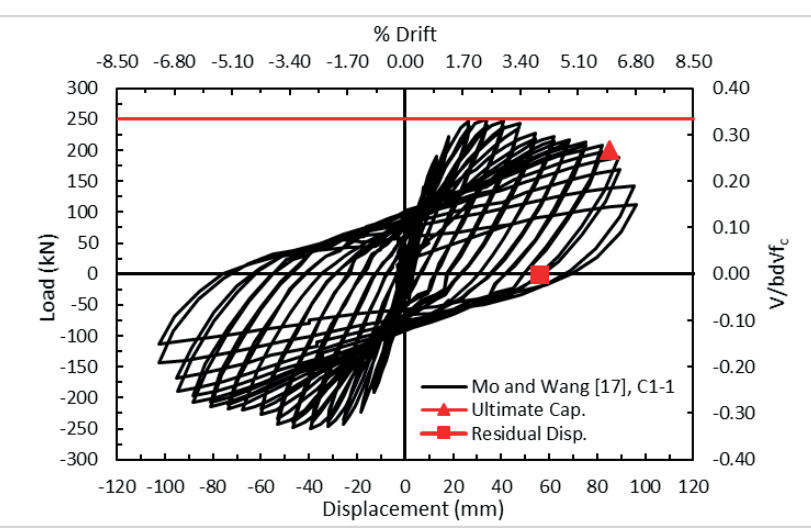

Fig. 5 Load-displacement curve of the Mo and Wang [17], C1-1

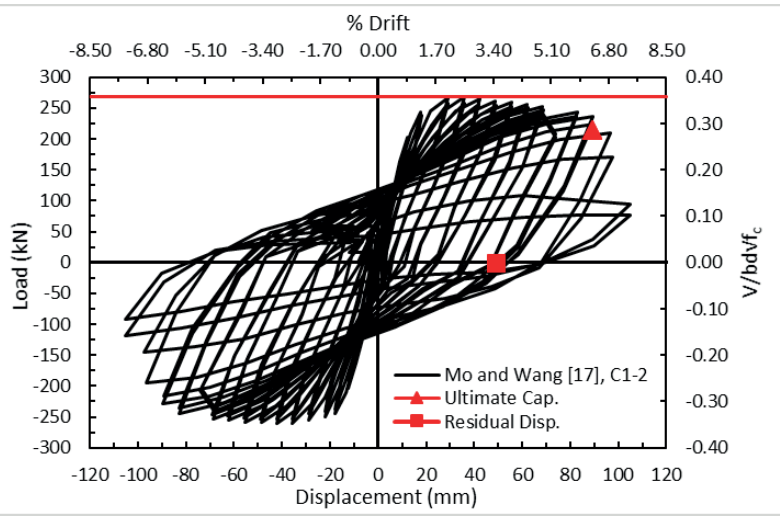

Fig. 6 Load-displacement curve of the Mo and Wang [17], C1-2



Fig. 7 Load-displacement curve of the Mo and Wang [17], C1-3

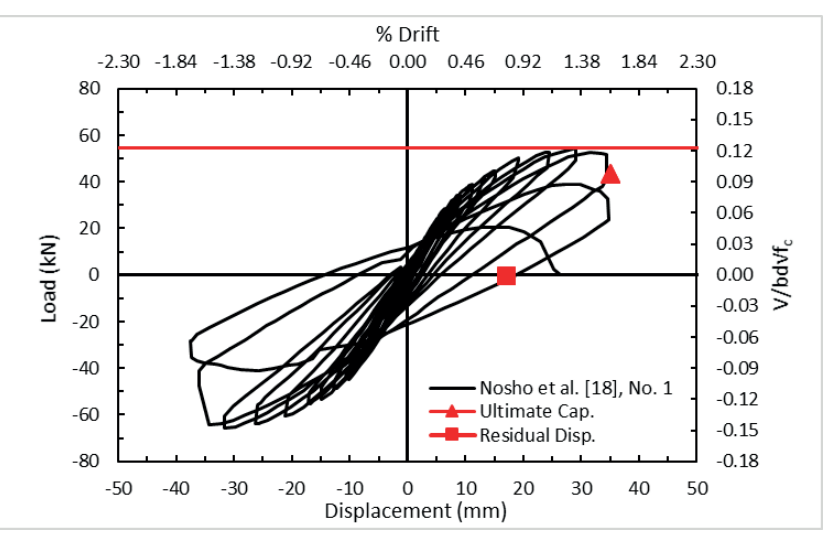

Fig. 8 Load-displacement curve of the Nosho et al. [18], No. 1



Fig. 9 Load-displacement curve of the Saatcioglu and Grira [19], BG-1

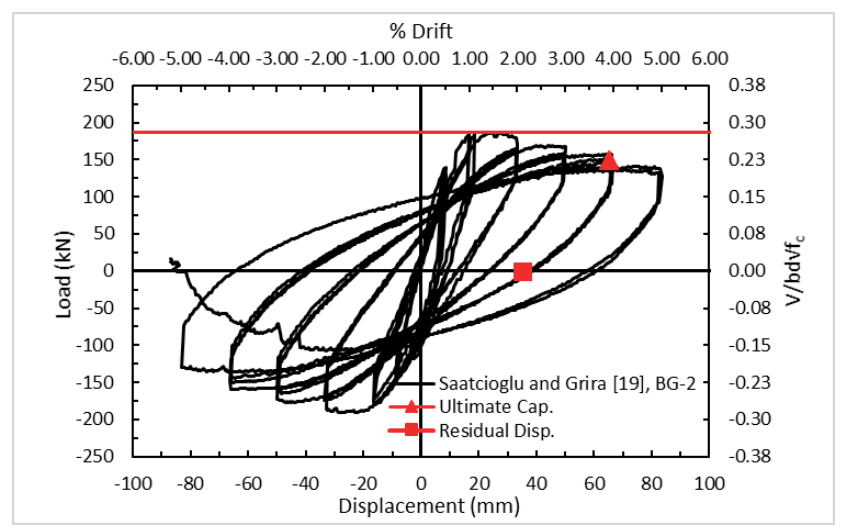

Fig. 10 Load-displacement curve of the Saatcioglu and Grira [19], BG-2

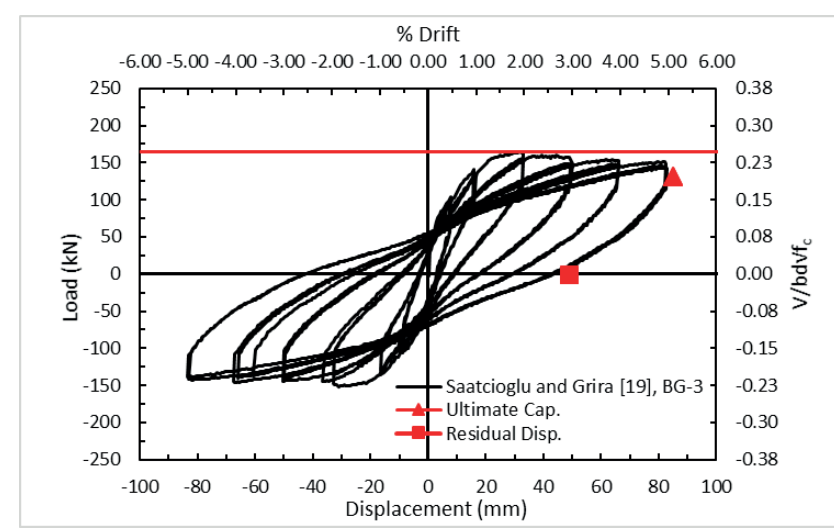

Fig. 11 Load-displacement curve of the Saatcioglu and Grira [19], BG-3 


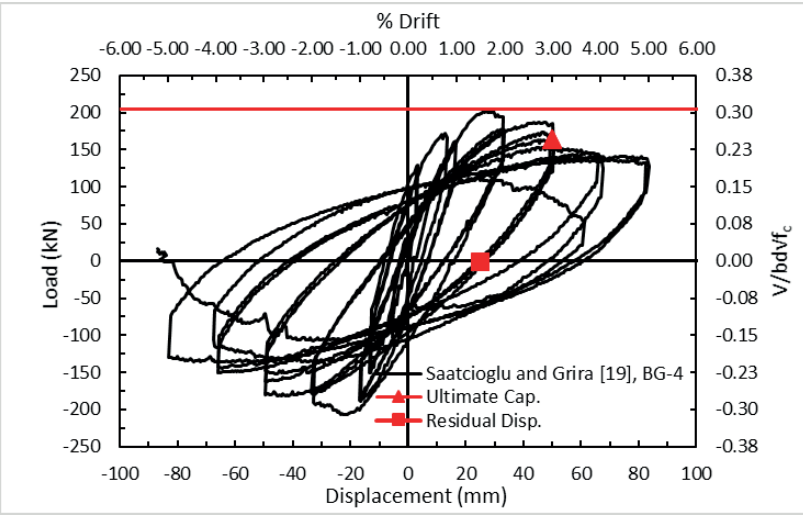

Fig. 12 Load-displacement curve of the Saatcioglu and Grira [19], BG-4

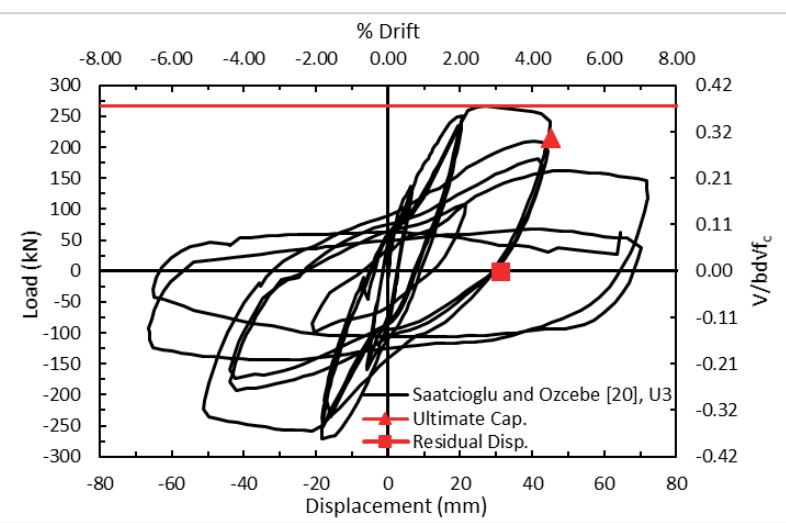

Fig. 13 Load-displacement curve of the Saatcioglu and Ozcebe [20], U3

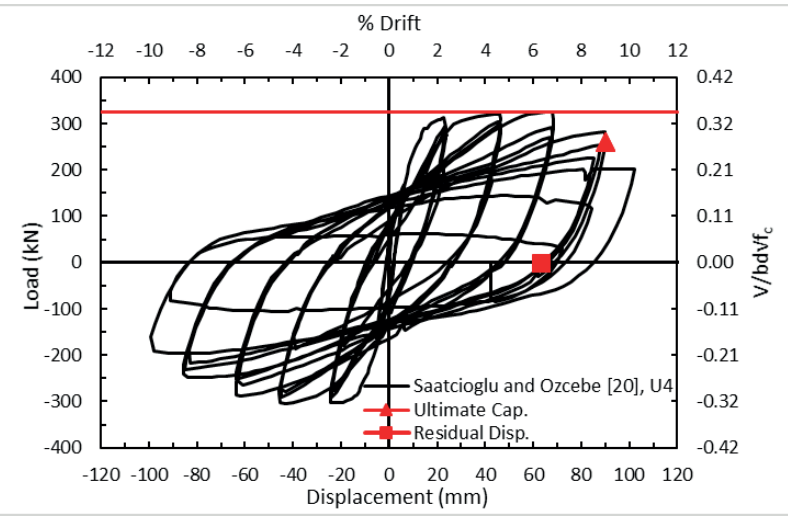

Fig. 14 Load-displacement curve of the Saatcioglu and Ozcebe [20], U4

\section{$\%$ Drift}

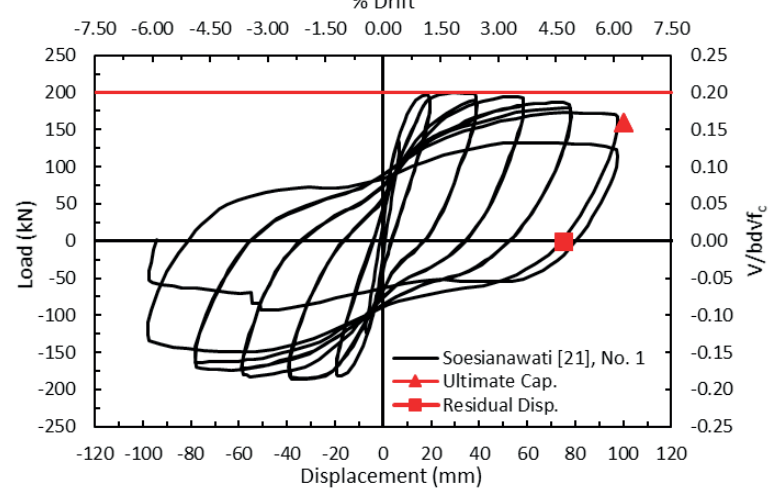

Fig. 15 Load-displacement curve of the Soesianawati [21], No. 1

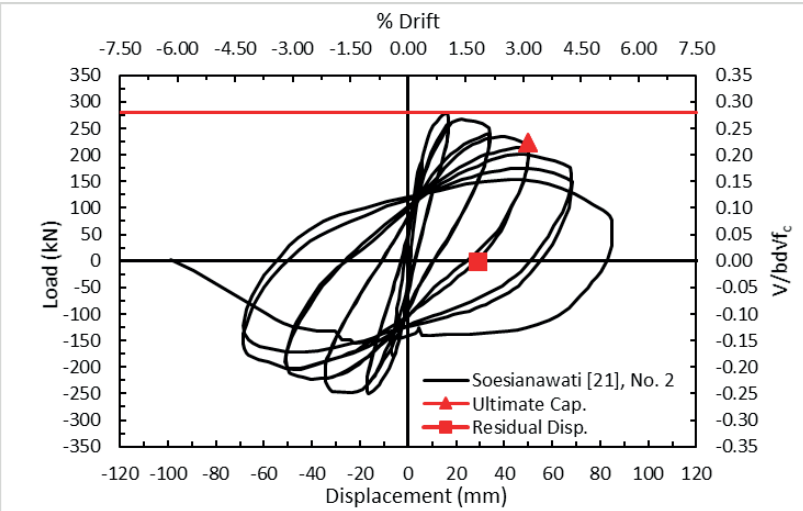

Fig. 16 Load-displacement curve of the Soesianawati [21], No. 2

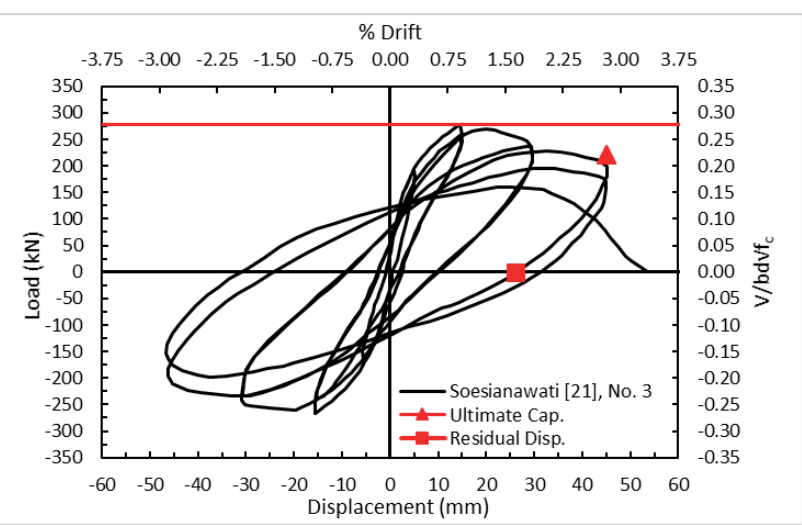

Fig. 17 Load-displacement curve of the Soesianawati [21], No. 3



Fig. 18 Load-displacement curve of the Soesianawati [21], No. 4

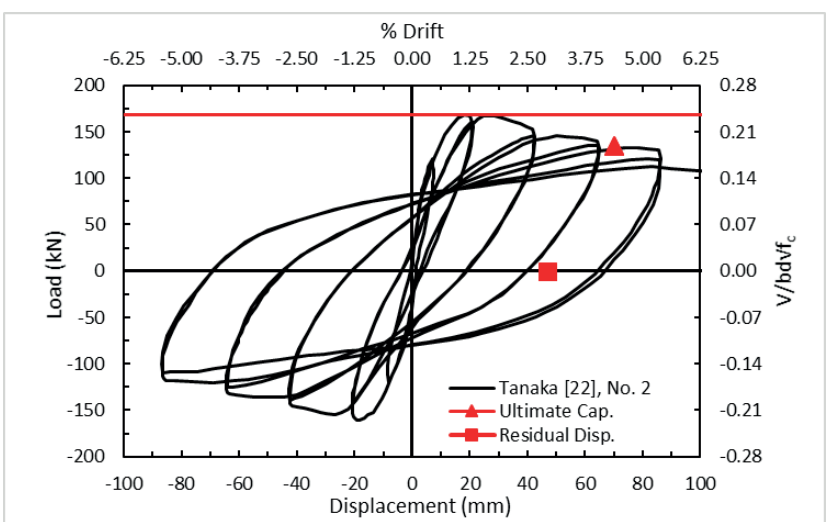

Fig. 19 Load-displacement curve of the Tanaka [22], No. 2 


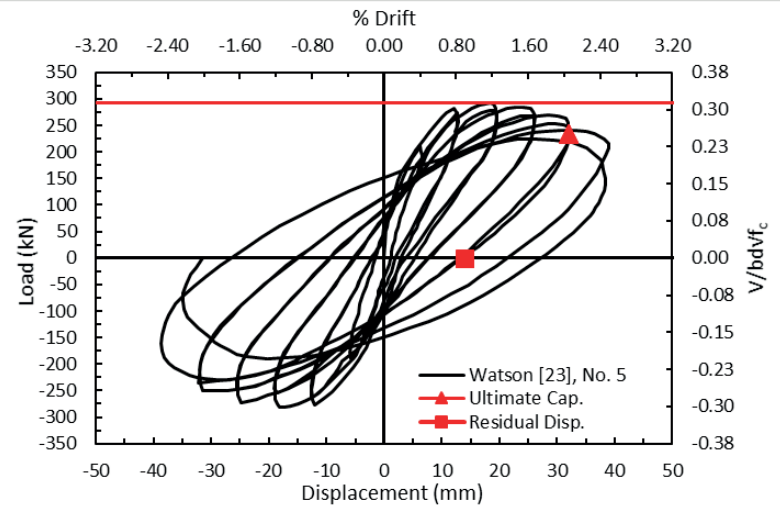

Fig. 20 Load-displacement curve of the Watson [23], No. 5

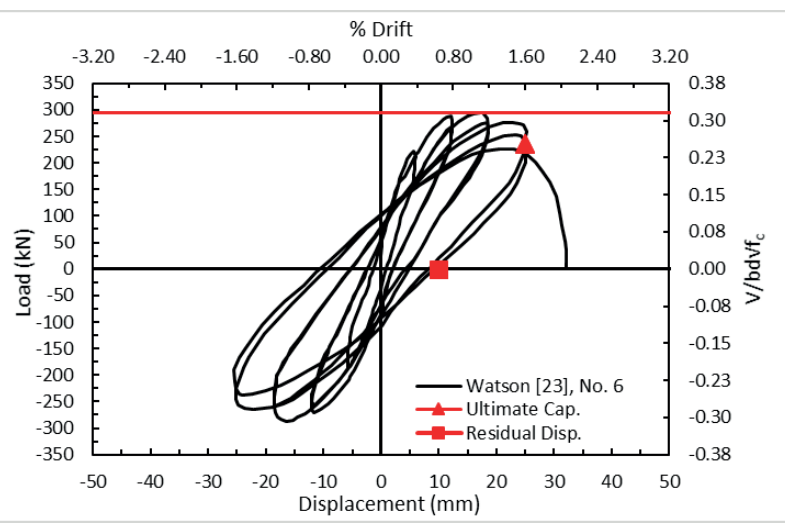

Fig. 21 Load-displacement curve of the Watson [23], No. 6



Fig. 22 Load-displacement curve of the Zahn [24], No. 7

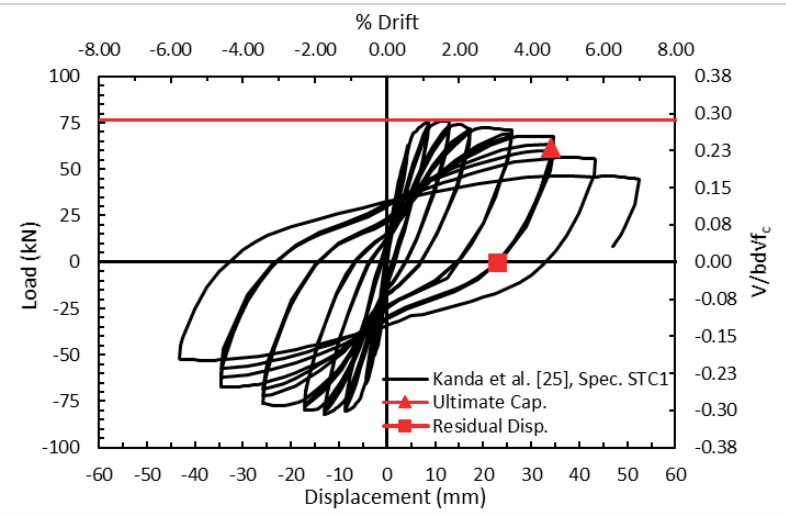

Fig. 23 Load-displacement curve of the Kanda et al. [25] Spec. STC1

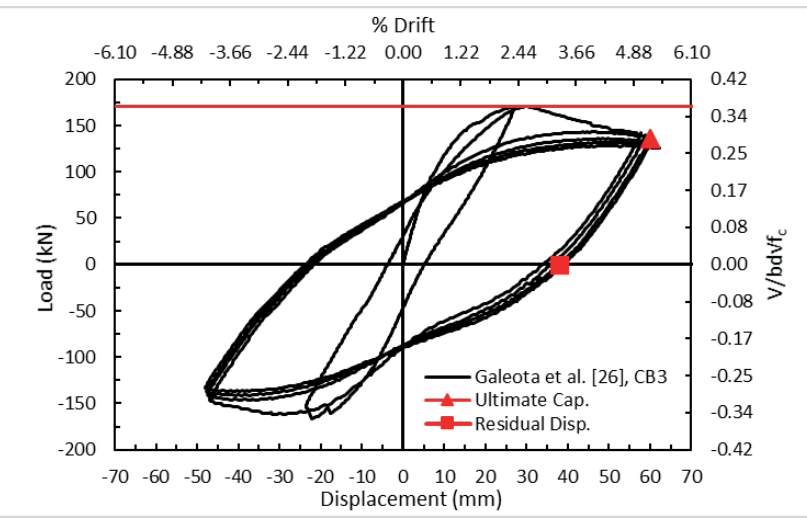

Fig. 24 Load-displacement curve of the Galeota et al. [26] CB3

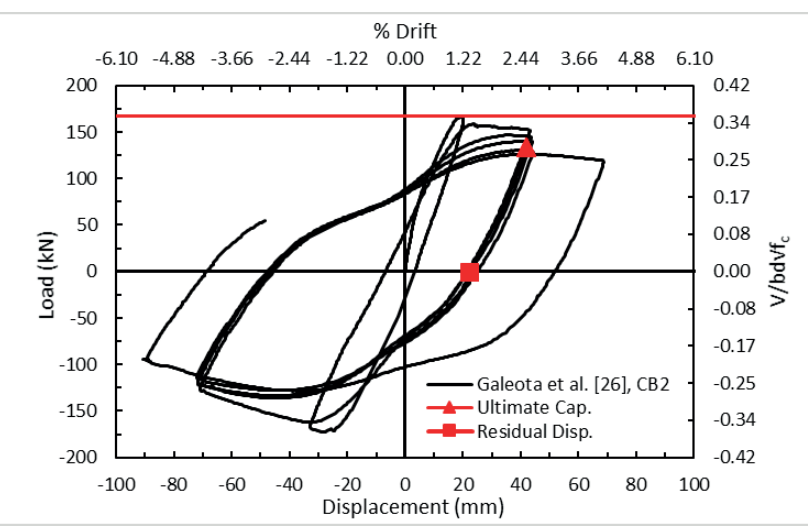

Fig. 25 Load-displacement curve of the Galeota et al. [26] CB2



Fig. 26 Load-displacement curve of the Wehbe et al. [27] A1

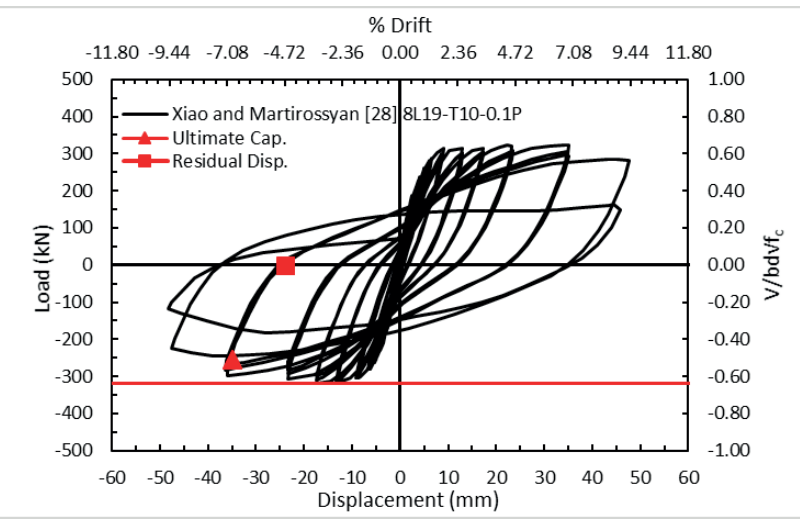

Fig. 27 Load-displacement curve of the Xiao and Martirossyan [28] 8L19-T10-0.1P 




Fig. 28 Load-displacement curve of the Xiao and Martirossyan [28] 8L19-T10-0.2P



Fig. 29 Load-displacement curve of the Xiao and Martirossyan [28] HC4-8L16-T10-0.1P

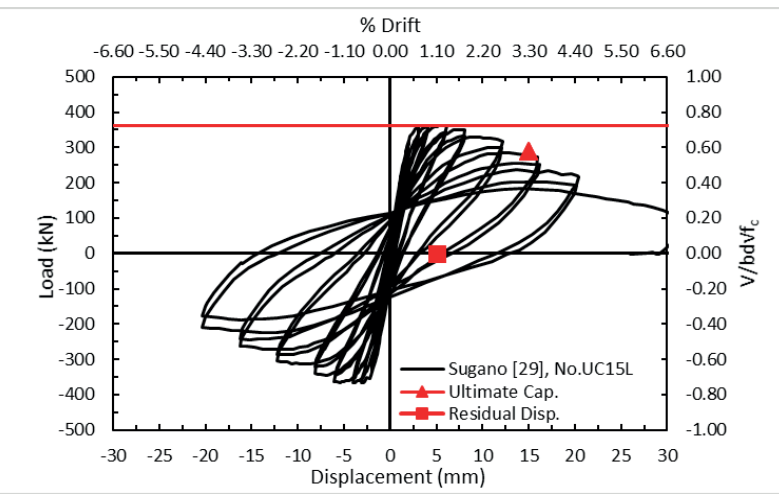

Fig. 30 Load-displacement curve of the Sugano [29] No. UC15L

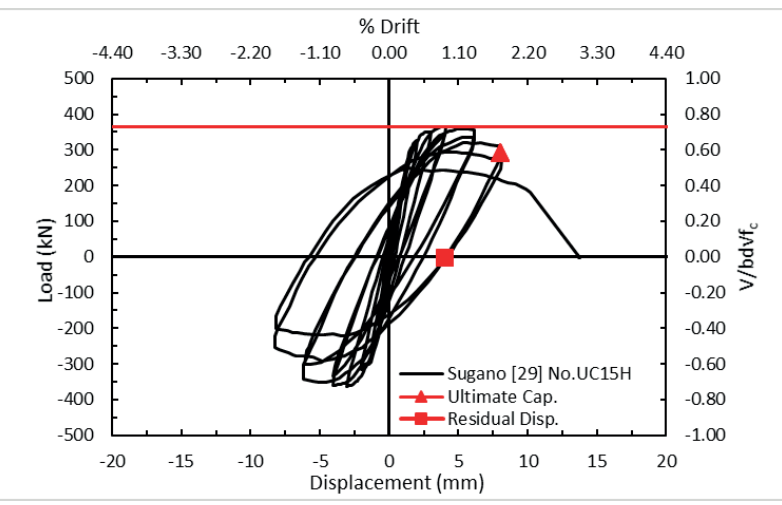

Fig. 31 Load-displacement curve of the Sugano [29] No. UC15H

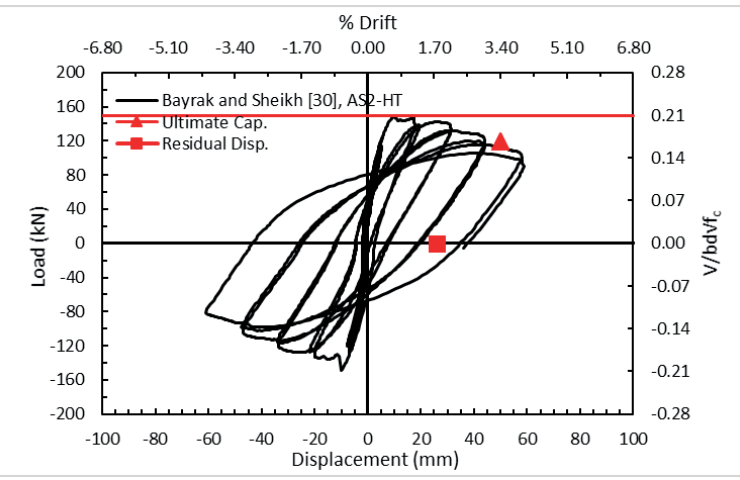

Fig. 32 Load-displacement curve of the Bayrak and Sheikh [30] AS2-HT

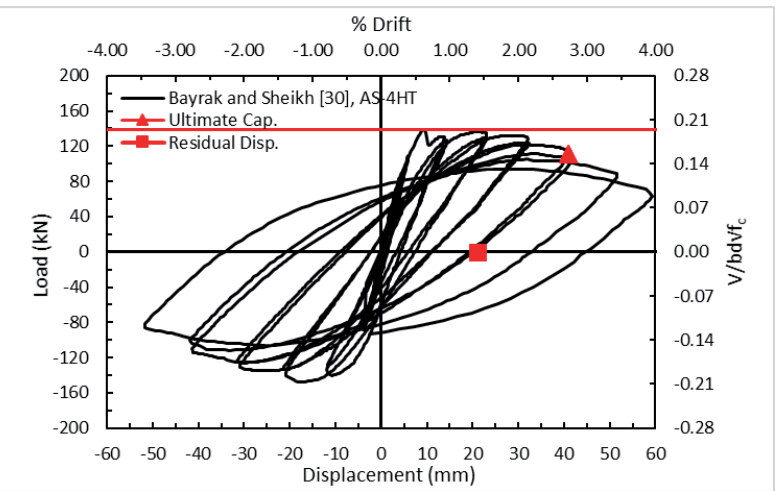

Fig. 33 Load-displacement curve of the Bayrak and Sheikh [30] AS-4HT

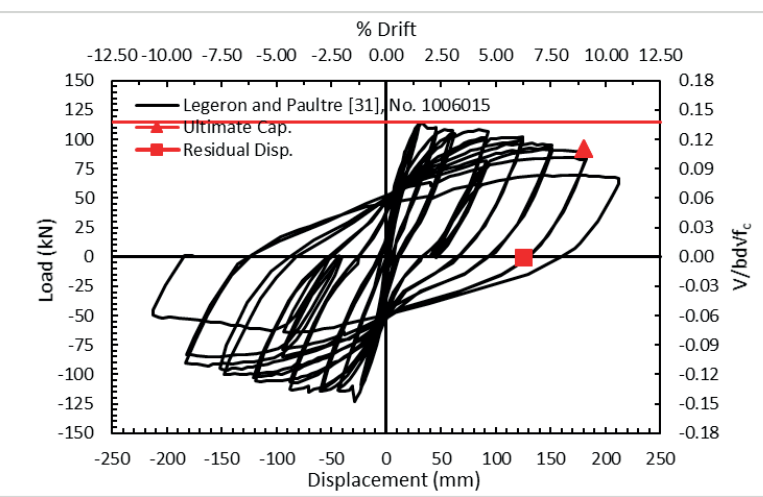

Fig. 34 Load-displacement curve of the Legeron and Paultre [31], No. 1006015



Fig. 35 Load-displacement curve of the Legeron and Paultre [31], No. 1006025 


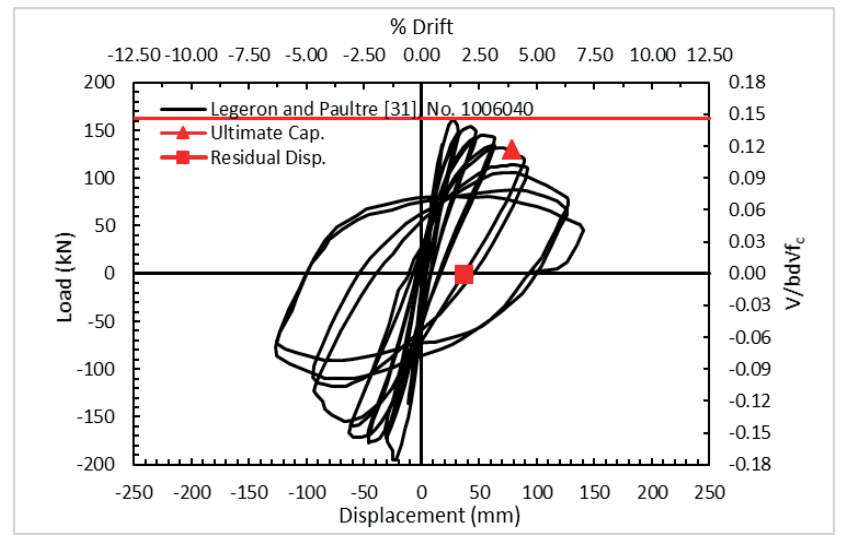

Fig. 36 Load-displacement curve of the Legeron and Paultre [31], No. 1006040

\section{Estimation of the residual drift}

Residual displacement take place over the yield displacement value due to the nonlinear behavior of the reinforced concrete column. When the figures are examined, permanent displacement values determined at the capacity point for each column have been marked. Residual displacement values of calculated for all columns are shown in the Table 3.

Where $\Delta u$ is the ultimate displacement capacity, $\Delta r$ is the residual displacement at ultimate capacity, $\theta_{u}$ is the ultimate drift ratio and $\theta_{r}$ is the residual drift ratio at ultimate capacity. When residual drift ratio were examined, it was seen that it was affected by various parameters. These interaction graphics are shown in Figs. 37-40.

When the Figures are examined, it is seen that the residual drift ratio of reinforced concrete columns is mostly related to the axial load level. In order to better understand this situation, the correlation matrix showing the relationship between the Statistica program and the parameters was determined. This correlation matrix is presented in the Table 4 [34].

The axial load level and the shear spanning to depth have positive correlation, while the transverse reinforcement ratio and the longitudinal reinforcement ratio have negative correlations. When the results of the columns are examined, residual displacement consist of the range of $40-80 \%$ of the capacity displacement value. The graphic representing this situation is shown in Fig. 41.

Approximately $50 \%$ residual displacement of the total displacement occurs in a column that has been damaged due to inelastic behavior. As it is known, reinforced concrete columns are definitely damaged during an earthquake. The most important indicator of this damage can be considered as residual displacement ratio. For this purpose,
Statistica program has been used to estimate the residual drift ratio. According to statistical analysis the most accurate estimation of the residual drift ratio is given in Eq. (3).

Table 3 Residual drift ratio of the columns

\begin{tabular}{|c|c|c|c|c|}
\hline Specimen Name & $\begin{array}{c}\Delta u \\
(\mathrm{~mm})\end{array}$ & $\begin{array}{c}\Delta r \\
(\mathrm{~mm})\end{array}$ & $\theta_{u}$ & $\theta_{r}$ \\
\hline Ang [15], No. 3 & 45 & 25 & 0.028 & 0.016 \\
\hline Ang [15], No. 4 & 61 & 40 & 0.038 & 0.025 \\
\hline Azizinamini et al. [16], NC-2 & 64 & 43 & 0.047 & 0.031 \\
\hline Azizinamini et al. [16], NC-4 & 38 & 23 & 0.028 & 0.017 \\
\hline Mo and Wang [17], C1-1 & 85 & 56 & 0.061 & 0.040 \\
\hline Mo and Wang [17], C1-2 & 89 & 49 & 0.064 & 0.035 \\
\hline Mo and Wang [17], C1-3 & 79 & 38 & 0.056 & 0.027 \\
\hline Nosho et al. [18], No. 1 & 35 & 17 & 0.016 & 0.008 \\
\hline Saatcioglu and Grira [19], BG-1 & 45 & 22 & 0.027 & 0.013 \\
\hline Saatcioglu and Grira [19], BG-2 & 65 & 35 & 0.040 & 0.021 \\
\hline Saatcioglu and Grira [19], BG-3 & 85 & 51 & 0.052 & 0.031 \\
\hline Saatcioglu and Grira [19], BG-4 & 50 & 25 & 0.030 & 0.015 \\
\hline Saatcioglu and Ozcebe [20], U3 & 60 & 38 & 0.060 & 0.038 \\
\hline Saatcioglu and Ozcebe [20], U4 & 90 & 61 & 0.090 & 0.061 \\
\hline Soesianawati [21], No. 1 & 100 & 72 & 0.063 & 0.045 \\
\hline Soesianawati [21], No. 2 & 50 & 29 & 0.031 & 0.018 \\
\hline Soesianawati [21], No. 3 & 45 & 26 & 0.028 & 0.016 \\
\hline Soesianawati [21], No. 4 & 40 & 23 & 0.025 & 0.014 \\
\hline Tanaka [22], No. 2 & 70 & 47 & 0.044 & 0.029 \\
\hline Watson [23], No. 5 & 32 & 14 & 0.020 & 0.009 \\
\hline Watson [23], No. 6 & 25 & 11 & 0.016 & 0.007 \\
\hline Zahn [24], No. 7 & 81 & 44 & 0.051 & 0.028 \\
\hline Kanda et al. [25]85STC-1 & 34 & 23 & 0.045 & 0.030 \\
\hline Galeota et al. [26] CB3 & 60 & 38 & 0.052 & 0.033 \\
\hline Galeota et al. [26] CB2 & 42 & 20 & 0.036 & 0.017 \\
\hline Wehbe et al. [27] A1 & 38 & 25 & 0.017 & 0.011 \\
\hline $\begin{array}{l}\text { Xiao and Martirossyan [28], } \\
\text { 8L19-T10-0.1P }\end{array}$ & 35 & 24 & 0.069 & 0.047 \\
\hline $\begin{array}{l}\text { Xiao and Martirossyan [28], } \\
8 \mathrm{~L} 19-\mathrm{T} 10-0.2 \mathrm{P}\end{array}$ & 29 & 20 & 0.057 & 0.039 \\
\hline $\begin{array}{l}\text { Xiao and Martirossyan [28], } \\
8 \mathrm{~L} 16-\mathrm{T} 10-0.1 \mathrm{P}\end{array}$ & 38 & 28 & 0.075 & 0.055 \\
\hline Sugano [29] UC15L & 15 & 5 & 0.033 & 0.011 \\
\hline Sugano [29] UC15H & 8 & 4 & 0.017 & 0.008 \\
\hline Bayrak and Sheikh [30] AS-2HT & 50 & 26 & 0.033 & 0.017 \\
\hline Bayrak and Sheikh [30] AS-4HT & 41 & 21 & 0.027 & 0.014 \\
\hline $\begin{array}{l}\text { Legeron and Paultre [31], } \\
\text { No. } 1006015\end{array}$ & 180 & 125 & 0.090 & 0.062 \\
\hline $\begin{array}{l}\text { Legeron and Paultre [31], } \\
\text { No. } 1006040\end{array}$ & 99 & 48 & 0.049 & 0.024 \\
\hline $\begin{array}{l}\text { Legeron and Paultre [31], } \\
\text { No. } 1006025\end{array}$ & 75 & 36 & 0.037 & 0.018 \\
\hline
\end{tabular}




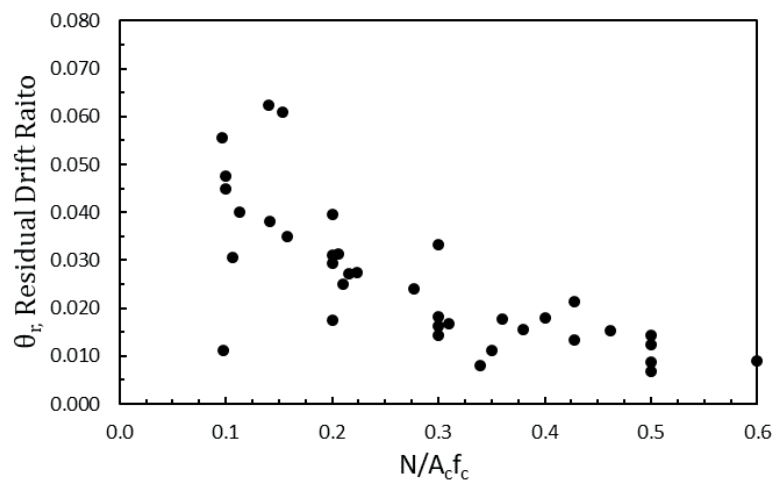

Fig. 37 Interaction between residual drift ratio and axial load ratio

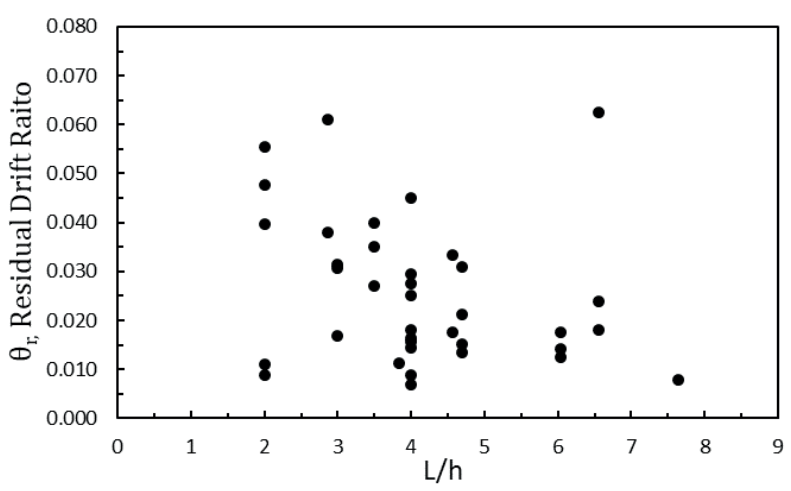

Fig. 38 Interaction between residual drift ratio and spanning to depth ratio

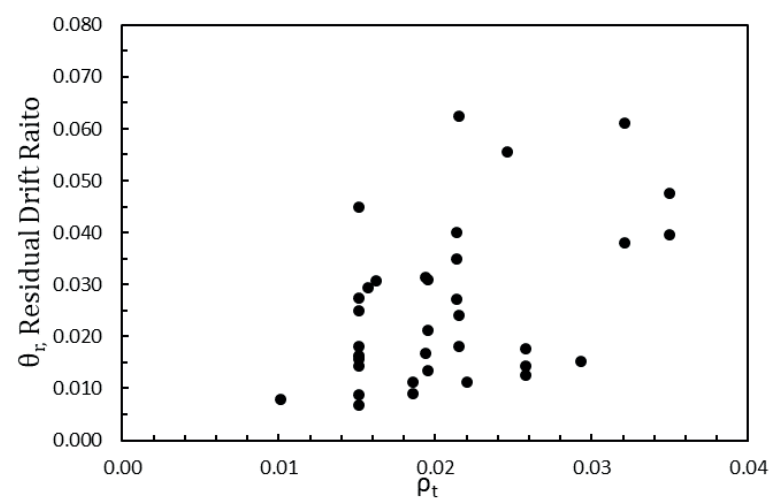

Fig. 39 Interaction between residual drift ratio and longitudinal reinforcement ratio

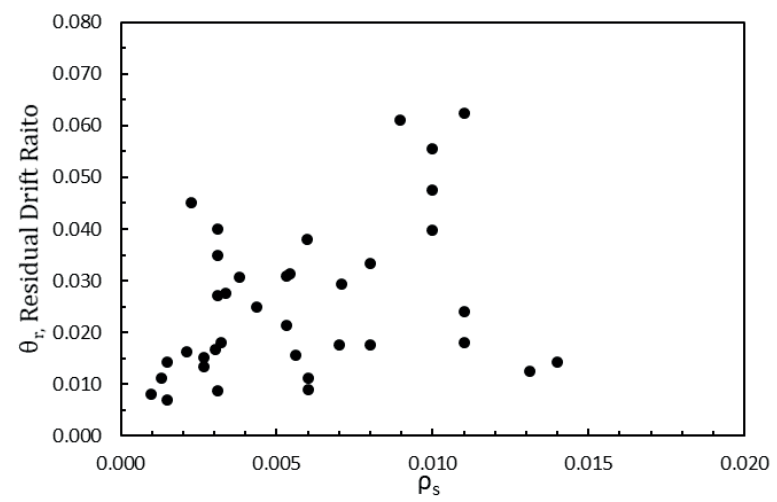

Fig. 40 Interaction between residual drift ratio and transverse reinforcement ratio

$$
\begin{aligned}
\theta_{r, e s t .}= & -1.67\left(\frac{N}{A_{c} f_{c k}}\right)^{-1.93}\left(\frac{L}{h}\right)^{-0.005}\left(\rho_{t}\right)^{1.88}+ \\
& \rho_{t}\left(\rho_{h}^{0.209}\right)\left(\frac{N}{A_{c} f_{c k}}\right)^{-1.36}
\end{aligned}
$$

The estimates of the proposed equation are compared with the experimental results in Fig. 42. The proposed equation accurately predicts residual drift ratio with a $89 \%$ correlation.

When the Fig. 42 is examined, it is seen that the proposed equation estimates the residual drift ratio very closely. This equation gives proper results in columns complying with seismic codes. In addition, this equation

Table 4 Correlation matrix of parameters of the columns

\begin{tabular}{lccccc}
\hline Parameter & $L / h$ & $N / A_{\sigma} f_{c}$ & $\rho_{t}$ & $\rho_{s}$ & $\theta_{r}$ \\
\hline$L / h$ & 1.00 & 0.47 & -0.34 & 0.00 & -0.54 \\
$N / A_{\sigma} f_{c}$ & 0.47 & 1.00 & -0.14 & 0.01 & -0.83 \\
$\rho_{t}$ & -0.34 & -0.14 & 1.00 & 0.53 & 0.49 \\
$\rho_{s}$ & 0.00 & 0.01 & 0.53 & 1.00 & 0.30 \\
$\theta_{r}$ & -0.54 & -0.83 & 0.49 & 0.30 & 1.00 \\
\hline
\end{tabular}

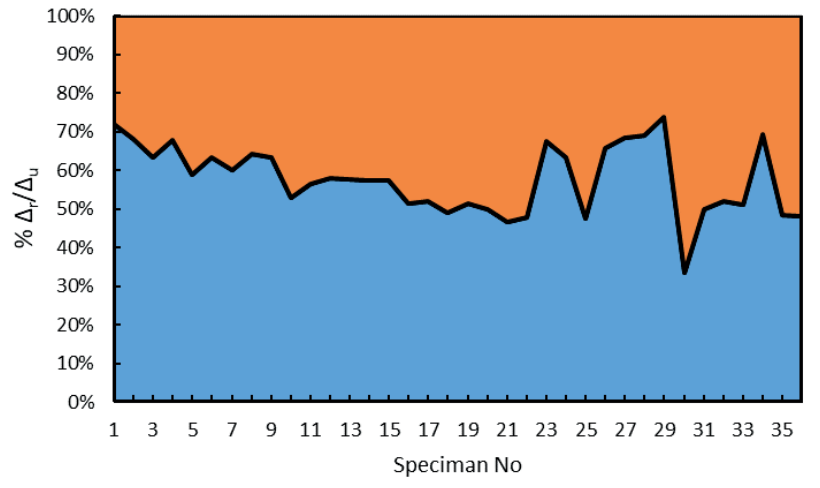

Fig. 41 Interaction between residual drift ratio and ultimate drift ratio

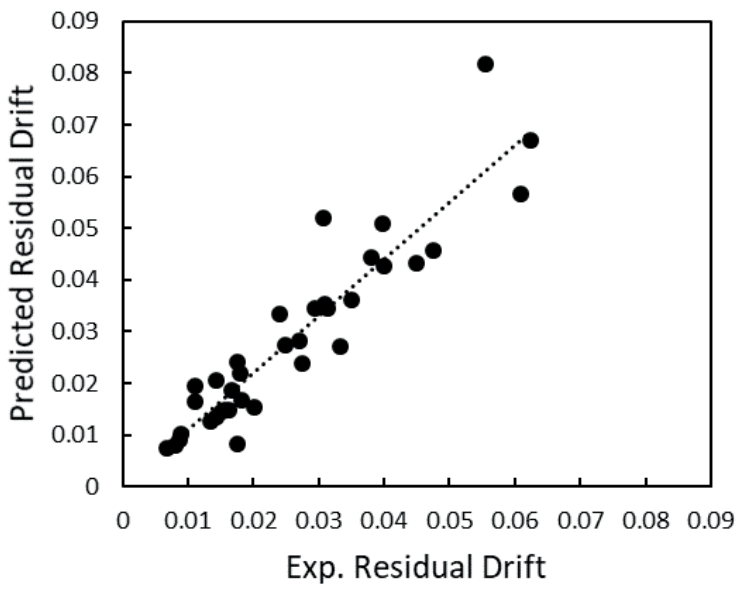

Fig. 42 Comparison with experimental residual drift and predicted residual drift 
does not give suitable results in very high strength concrete (e.g.: C60 and over C60) and very high axial load levels (e.g.: between $0.6 \mathrm{~N} / A_{c} f_{c}$ and $0.9 \mathrm{~N} / A_{c} f_{c}$ ).

\section{Estimation ultimate displacement capacity}

Within the scope of this study, the residual drift ratio of reinforced concrete columns under the ultimate displacement was estimated. According to Fig. 41, it is seen that reinforced concrete columns have an average of $60 \%$ residual displacement under ultimate displacement capacity. In addition, axial load level and span to depth ratio seem to be the most important parameters that changes the percentage of residual displacement. The curve showing the relationship between these parameters are presented in Figs. 43-44.

In order to simplify the relation, it has expressed depending on the axial load level that affects the most. The effect of other parameters is applied in Eq. (3). Since Eq. (3) is used in Eq. (4), it affects the result in other parameters. The relationship between these two parameters is given in Eq. (4).

$$
(\%)^{\Delta_{r}} / \Delta_{u}=41.49\left(\frac{N}{A_{c} f_{c}}\right)^{-0.23}
$$

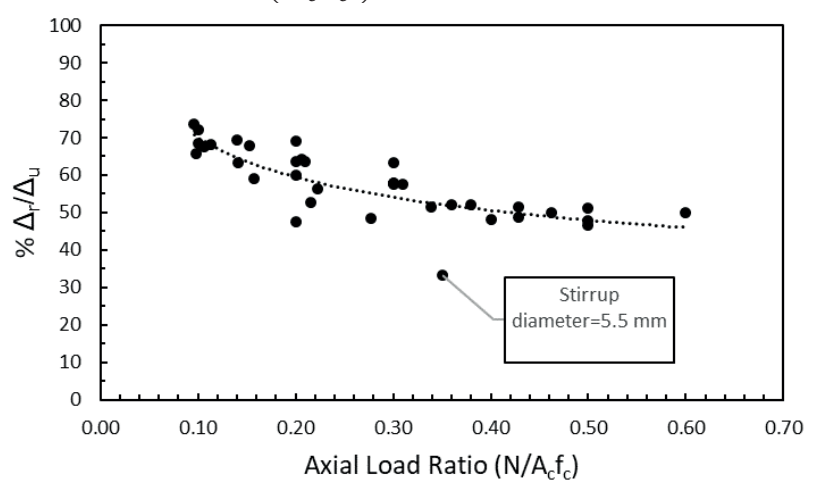

Fig. 43 The relationship between axial load ratio and residual displacement to ultimate displacement



Fig. 44 The relationship between span to depth ratio $(L / h)$ and residual displacement to ultimate displacement
After necessary simplification in the Eq. (4), the ultimate displacement capacity can be expressed with the Eq. (5) for the collapse prevented performance level.

$$
\begin{aligned}
\Delta_{r} & =\theta_{r} L \\
\Delta_{u} & =\frac{\Delta_{r}}{0.4149\left(\frac{N}{A_{c} f_{c}}\right)^{-0.23}}
\end{aligned}
$$

Comparison of the ultimate displacement capacity and experimental ultimate displacement capacity calculated according to Eq. (5) is shown in Fig. 45.

According to the study for a limited number of columns, the proposal equation has made predicts close to the real value.

\section{Analytical results}

In order to verify this study, reinforced concrete columns has modeled in the SeismoStruct program [35]. Properties of columns created in SeismoStruct program are presented in the Table 5.

The schematic cross-section and loading arrangement of the columns are shown in Fig. 46.



Fig. 45 Comparison with experimental displacement capacity and predicted ultimate displacement capacity

Table 5 Properties of the analytical columns

\begin{tabular}{lcccc}
\hline Specimen Name & $N / A_{c} f_{c}$ & $L / h$ & $\rho_{t}$ & $\phi_{s} / s$ \\
\hline S-10-3-01-50 & 0.1 & 3 & 0.01 & $\phi 8 / 50$ \\
S-40-3-01-50 & 0.4 & 3 & 0.01 & $\phi 8 / 50$ \\
S-10-3-01-100 & 0.1 & 3 & 0.01 & $\phi 8 / 100$ \\
S-40-3-01-100 & 0.4 & 3 & 0.01 & $\phi 8 / 100$ \\
S-10-5-01-50 & 0.1 & 5 & 0.01 & $\phi 8 / 50$ \\
S-40-5-01-50 & 0.4 & 5 & 0.01 & $\phi 8 / 50$ \\
\hline
\end{tabular}

Where $N / A_{c} f_{c}$ the axial load level, $L / h$ is the span to depth ratio, $\rho_{t}$ is a longitudinal reinforcement ratio, $\phi_{s}$ is transverse reinforcement diameter and $s$ is hoop spacing. 




Fig. 46 Schematic cross section and loading assembly

Same test procedure has been applied to all column. Same lateral displacement profile has been used in all columns. For each column, one full cycle of loading has been performed in the pre-yield stage. The pre-yield stage consisted of $0.5 \Delta_{y}$ and $0.25 \Delta_{y}$. Then, the columns have been subjected to cyclic loading with increasing amplitudes after every three cycles up to failure. Comparison of analytical results is shown in the Figs. 47-52.

When the results are examined, it is seen that the equation proposed in this study is compatible with the analytical results. It is determined in the graphs that the correlation obtained from the experimental studies predict ultimate displacement and residual displacement well in analytical models.

\section{Conclusions}

In this study, the analytical calculation of the residual drift ratio of the reinforced concrete columns under the ultimate displacement capacity was investigated. The determined results in the study are listed as follows:

- The residual drift ratio can be shown as the most important indicator of the damage state under the earthquake load or operating loads of reinforced concrete columns. According to experimental results, approximately $0.6 \Delta_{u}$ value residual displacement occurs under the displacement capacity of reinforced concrete columns.

- The residual drift ratio required for the collapse prevented performance level of the columns whose axial load level, shear span and reinforcements ratios are known can be calculated. In this way, the performance level of the existing columns depending on the residual drift ratio can be determined quickly and without cost.
- Using residual drift ratio the displacement capacity of reinforced concrete columns can be estimated. Although there are wide range of values in the study for a limited number of columns, ultimate displacement capacity estimation close to experimental ultimate displacement capacity has been made.

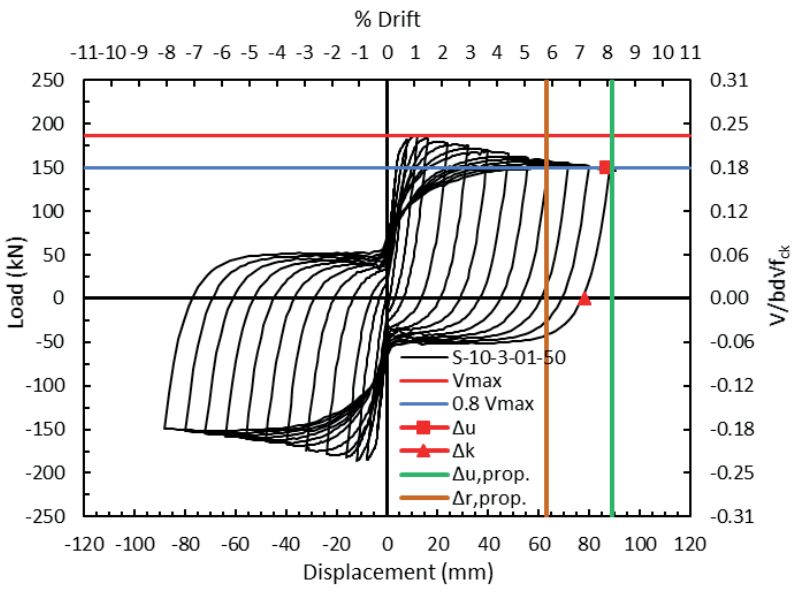

Fig. 47 Load-displacement curve of S10-3-01-50 column

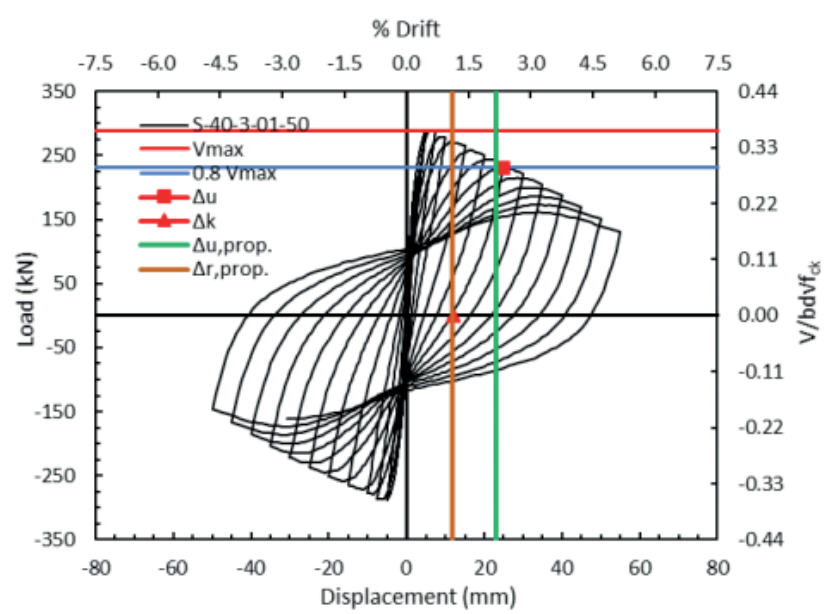

Fig. 48 Load-displacement curve of S40-3-01-50 column

$\%$ Drift

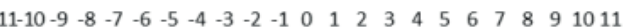

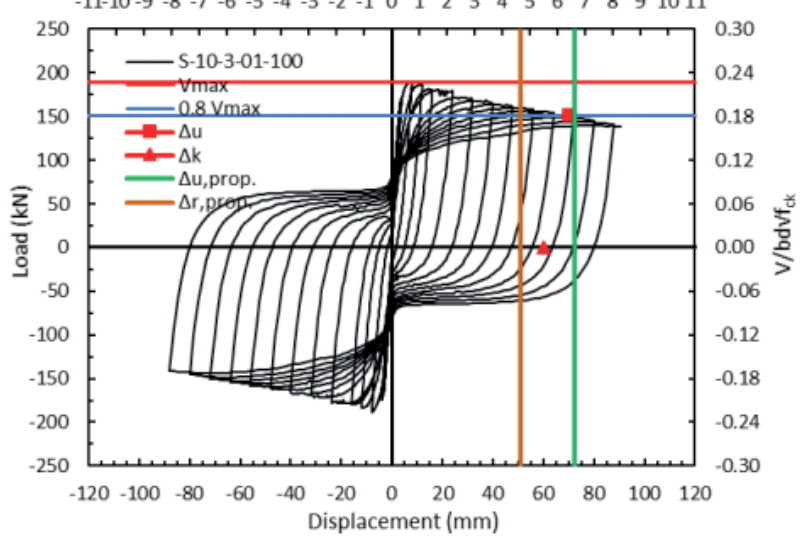

Fig. 49 Load-displacement curve of S10-3-01-100 column 


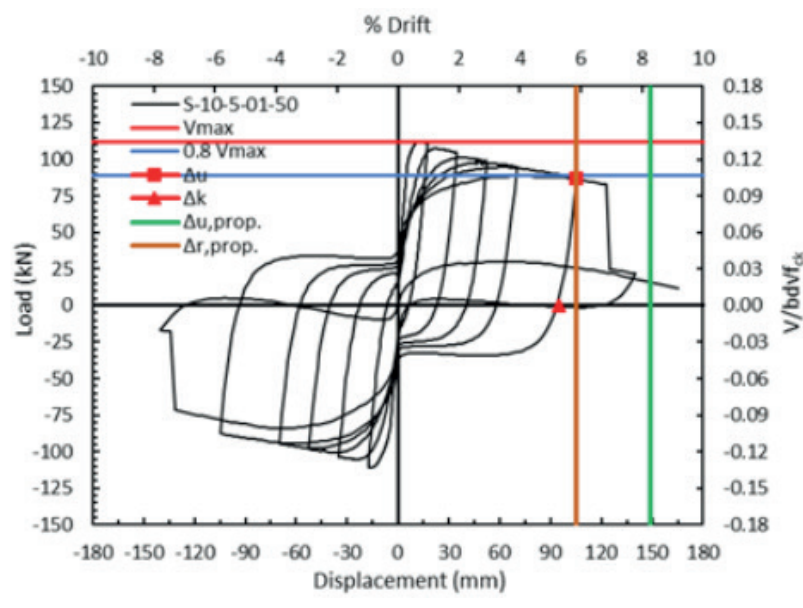

Fig. 51 Load-displacement curve of S10-5-01-50 column



Fig. 52 Load-displacement curve of S40-5-01-50 column

$\%$ Drift

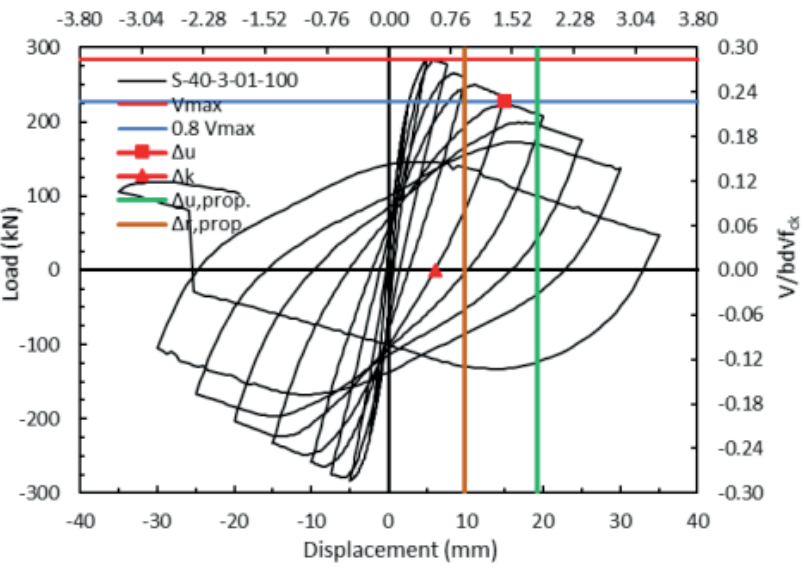

Fig. 50 Load-displacement curve of S40-3-01-100 column

\section{References}

[1] Ying, M., Jin-xin, G. "Seismic Failure Modes and Deformation Capacity of Reinforced Concrete Columns under Cyclic Loads", Periodica Polytechnica Civil Engineering, 62(1), pp. 80-91, 2018. https://doi.org/10.3311/PPci.9893

[2] Labibzadeh, M., Jamalpour, R., Jing, D. H., Khajehdezfuly, A. "A Numerical Comparison between Spiral Transverse RC and CFST Columns under Loads of Varying Eccentricities", Periodica Polytechnica Civil Engineering, 63(4), pp. 1171-1182, 2019. https://doi.org/10.3311/PPci.14177

[3] Mortezaei, A. "Plastic Hinge Length of RC Columns under the Combined Effect of Near-Fault Vertical and Horizontal Ground Motions", Periodica Polytechnica Civil Engineering, 58(3), pp. 243-253, 2014

https://doi.org/10.3311/PPci.7329

[4] Lehman, D., Moehle, J., Mahin, S., Calderone, A., Henry, L. "Experimental Evaluation of the Seismic Performance of Reinforced Concrete Bridge Columns", Journal of Structural Engineering, 130(6), pp. 869-879, 2004.

https://doi.org/10.1061/(ASCE)0733-9445(2004)130:6(869)
[5] Erduran, E., Yakut, A. "Drift based damage functions for reinforced concrete columns", Computers \& Structures, 82(2-3), pp. 121-130, 2004.

https://doi.org/10.1016/j.compstruc.2003.10.003

[6] Priestley, M. J. N., Kowalsky, M. J. "Direct displacement-based seismic design of concrete buildings", Bulletin of the New Zealand Society for Earthquake Engineering, 33(4), pp. 421-444, 2000. https://oi.org/10.5459/bnzsee.33.4.421-444

[7] Goodnight, J. C., Kowalsky, M. J., Nau, J. M. "Effect of Load History on Performance Limit States of Circular Bridge Columns", Journal of Bridge Engineering, 18(12), pp. 1383-1396, 2013. https://doi.org/10.1061/(ASCE)BE.1943-5592.0000495

[8] Cheng, H., Li, H., Wang, D., Sun, Z., Li, G., Jin, J. "Research on the influencing factors for residual displacements of RC bridge columns subjected to earthquake loading", Bulletin of Earthquake Engineering, 14, pp. 2229-2257, 2016. https://doi.org/10.1007/s10518-016-9902-y

[9] Yazgan, U., Dazio, A. "The use of post-earthquake residual displacements as a performance indicator in seismic assessment", Georisk: Assessment and Management of Risk for Engineered Systems and Geohazards, 5(1), pp. 59-76, 2011. https://doi.org/10.1080/17499511003679964 
[10] Bae, S., Bayrak, O. "Plastic Hinge Length of Reinforced Concrete Columns", ACI Structural Journal, 105(3), pp. 290-300, 2008. https://oi.org/10.14359/19788

[11] Vui, V. C., Hamid, R. R., Mahmud, A., Hassan, B. "A new damage index for reinforced concrete structures", Earthquakes and Structures, 6(6), pp. 581-609, 2014. https://doi.org/10.12989/eas.2014.6.6.581

[12] TBEC "Turkey Building Earthquake Regulation", [online] Available at: https://www.afad.gov.tr/turkiye-bina-deprem-yonetmeligi

[13] Panagiotakos, T. B., Fardis, M. N. "Deformations of Reinforced Concrete Members at Yielding and Ultimate", ACI Structural Journal, 98(2), pp. 135-148, 2001. https://doi.org/10.14359/10181

[14] Berry, M., Parrish, M., Eberhard, M. "PEER Structural Performance Database User's Manual (Version 1.0)", [pdf] Pacific Engineering Research Center, University of California, Berkeley, CA, USA, 2004. Available at: https://nisee.berkeley.edu/spd/performance database_manual_1-0.pdf

[15] Ang, B. G. "Ductility of Reinforced Concrete Bridge Piers Under Seismic Loading", MSc Thesis, University of Canterbury, 1981. https://doi.org/10.26021/2262

[16] Azizinamini, A., Johal, L. S., Hanson, N. W., Musser, D. W., Corley, W. G. "Effects of Transverse Reinforcement on Seismic Performance of Columns - A Partial Parametric Investigation", [pdf] Construction Technology Laboratories, Skokie, IL, USA, Rep. NSF/ ENG-88014, 1988. Available at: https://nehrpsearch.nist.gov/static/ files/NSF/PB89148068.pdf

[17] Mo, Y. L., Wang, S. J. "Seismic Behavior of RC Columns with Various Tie Configurations", Journal of Structural Engineering, 126(10), pp. 1122-1130, 2000 https://doi.org/10.1061/(ASCE)0733-9445(2000)126:10(1122)

[18] Nosho, K., Stanton, J., MacRae, G. "Retrofit of rectangular reinforced concrete columns using tonen forca tow sheet carbon fiber wrapping", Department of Civil Engineering, University of Washington, Seattle, WA, USA, Rep. SGEM, 96-2, 1996.

[19] Saatcioglu, M., Grira, M. "Confinement of Reinforced Concrete Columns with Welded Reinforced Grids", ACI Structural Journal, 96(1), pp. 29-39, 1999 https://doi.org/10.14359/593

[20] Saatcioglu, M., Ozcebe, G. "Response of Reinforced Concrete Columns to Simulated Seismic Loading", ACI Structural Journal, 86(1), pp. 3-12, 1989. https://doi.org/10.14359/2607

[21] Soesianawati, M. T. "Limited Ductility Design of Reinforced Concrete Columns", MSc Thesis, University of Canterbury, 1986. https://doi.org/10.26021/2554

[22] Tanaka, H. "Effect of Lateral Confining Reinforcement on the Ductile Behavior of Reinforced Concrete Columns", PhD Thesis, University of Canterbury, 1990. https://doi.org/10.26021/3137

[23] Watson, S. "Design of Reinforced Concrete Frames of Limited Ductility", PhD Thesis, University of Canterbury, 1989. https://doi.org/10.26021/1426
[24] Zahn, F. A. "Design of Reinforced Bridge Columns for Strength and Ductility", PhD Thesis, University of Canterbury, 1986. https://doi.org/10.26021/2893

[25] Kanda, M., Shirai, N., Adachi, H., Sato, T. "Analytical Study on Elasto-Plastic Hysteretic Behaviors of Reinforced Concrete Members", Transactions of the Japan Concrete Institute, 10, pp. 257-264, 1988. [in Japanese]

[26] Galeota, D., Giammatteo, M. M., Marino, R. "Seismic Resistance of High Strength Concrete Columns", [pdf] In: Proceedings of the Eleventh World Conference on Earthquake Engineering, Acapulco, Mexico, 1996, Paper No. 1390. Available at: http://www.iitk.ac.in/ nicee/wcee/article/11_1390.PDF

[27] Wehbe, N. I., Saiidi, M. S., Sanders, D. H. "Seismic Performance of Rectangular Bridge Columns with Moderate Confinement", ACI Structural Journal, 96(2), pp. 248-258, 1999. https://doi.org/10.14359/616

[28] Xiao, Y., Martirossyan, A. "Seismic Performance of High-Strength Concrete Columns", Journal of Structural Engineering, 124(3), pp. 241-251, 1998. https://doi.org/10.1061/(ASCE)0733-9445(1998)124:3(241)

[29] Sugano, S. "Seismic Behavior of Reinforced Concrete Columns Which used Ultra-High-Strength Concrete", [pdf] In: Proceedings of the Eleventh World Conference on Earthquake Engineering, Acapulco, Mexico, 1996, Paper No. 1383. Available at: https:// www.iitk.ac.in/nicee/wcee/article/11 1383.PDF

[30] Bayrak, O., Sheikh, S. A. "Confinement steel requirements for high strength concrete columns", [pdf] In: Proceedings of the Eleventh World Conference on Earthquake Engineering, Acapulco, Mexico, 1996, Paper No. 463. Available at: https://www.iitk.ac.in/nicee/ wcee/article/11_463.PDF

[31] Legeron, F., Paultre, P. "Behavior of High-Strength Concrete Columns under Cyclic Flexure and Constant Axial Load", ACI Structural Journal, 97(4), pp. 591-601, 2000. https://doi.org/10.14359/7425

[32] CEN "BS EN 1998-1:2004 Eurocode 8: Design of structures for earthquake resistant - Part 1: General rules, seismic actions and rules for buildings", [pdf] European Committee for Standardization, Brussels, Belgium, 2003. Available at: http://www.phd.eng.br/ wp-content/uploads/2015/02/en.1998.1.2004.pdf

[33] ASCE "Prestandard and commentary for the seismic rehabilitation of buildings", [pdf] Federal Emergency Management Agency, Washington, DC, USA, Rep. FEMA-356, 2000. Available at: https:// www.fema.gov/media-library-data/20130726-1444-20490-5925/ fema_356.pdf

[34] StatSoft "Statistica 10.0", [online] Available at: https://statistica. software.informer.com/10.0/

[35] SeismoSoft "SeismoStruct, Civil Engineering Software for Structural Assessment and Structural Retrofitting", [online] Available at: https://seismosoft.com/products/seismostruct/ 